\title{
Policy Considerations on the Interplay between State Aid Control and Competition Law
}

\author{
Maria João Melícias
}

\begin{abstract}
Under the broad topic of the interplay between state aid and competition law, this article addresses the following related lines of discussion: (i) the goals and some of the political rationales of state aid control; (ii) a brief illustration of some of the harm caused by state aid, including a distinction between its anticompetitive and distortive effects; (iii) a description of the Portuguese legal and institutional framework on domestic state aid, including the underlying rationale for this institutional design; (iv) an assessment of the policy concerns that a scenario whereby the AdC would hold full-fledged enforcement powers against state aid might raise, and, finally (v) the competition advocacy role played by the AdC in relation to state-induced competition distortions, such as state aid or subsidies. The article concludes by putting into context the references included in recent EU policy statements on the importance of "fair competition" or "equitable markets" and recalls the need to avoid that similar standards contaminate antitrust enforcement or merger control, given the risks that "mixed" policy objectives in those domains might entail. It signals, in any event, the virtues of this new found rhetoric: the fact that it helps to engage the common citizen on the importance of competition. Such popular, less technocratic approach can be instrumental in bringing competition enforcement "down to earth".
\end{abstract}

KEY WORDS: state aid control, policy goals, public interest, fairness, consumer welfare

\footnotetext{
* Commissioner of the Autoridade da Concorrência (AdC), 1050-037 Lisboa, Portugal. The views expressed here are the author's own and do not necessarily reflect those of the AdC.mjmelicias@ concorrencia.pt. This article reflects, with minor adjustments, the speech made on the occasion of the international Conference on "A New Approach to State Aid", hosted by the Portuguese Catholic University - Porto Law School, held in Porto, on 19 March 2016.
} 


\section{Introduction}

Despite the state aid prohibition laid down in the Portuguese Competition Act, control of state aid is not part of what I usually call the AdC's "core business", i.e. competition law enforcement. Throughout my presentation I will try to explain why this is the case, by addressing the following related lines of discussion on the interplay between state aid law and competition law (the latter being addressed to undertakings, rather than sovereign states), namely: (i) the goals of state aid law; (ii) an illustration of some of the negative effects caused by state aid; (iii) the Portuguese legal and institutional framework on domestic state aid, including the underlying rationale for this institutional design; (iv) an assessment of the policy concerns that a scenario whereby the AdC would hold full-fledged enforcement powers against state aid might raise, and, finally (v) the role played by the AdC in relation to state aid and other forms of state-induced competition distortions or breaches to the so-called principle of "competitive neutrality".

\section{Goals of state aid control - the negative effects of state aid measures}

In order to set the scene for the debate, I usually find it useful to take a step back in order to ask ourselves, from a public policy perspective, why we should be concerned about state aid or subsidies at all, both within Portugal, at supranational level or elsewhere.

In other words, an appropriate interpretation of the rules on state aid control requires that one determines, first and foremost, what the control system is meant for, namely which goals it is designed to achieve or which type of harm it is striving to avoid.

\subsection{Economic rationales - addressing inefficiencies caused by state aid}

The usual economic rationales underpinning state aid control include addressing production, allocative or dynamic inefficiencies supposedly created by state aid measures, inter alia, the fact that subsidies may lessen incentives to innovate, raise quality or cut production costs, both for efficient and inefficient firms. In this respect, it is usually considered that efficient firms' incentives are likely to be reduced if they expect that their competitive advantage will be offset by the granting of an aid to their rivals. As to inefficient firms, aids may encourage them to engage in excessively risky investments or they may be less inclined, as a result, to address the source 
of their inefficiencies. Other examples of possible negative effects caused by state aid include the fact that aids interfere with market signals, since when one or more producers receive favours from the state, consumers might not face the real costs of their choices. Furthermore, the provision of subsidies to specific firms may yield capital misallocation: if such subsidies are granted to inefficient firms, they shift production towards less efficient units, thereby increasing total production costs and/or lowering the quantity of output produced. ${ }^{1}$

\subsection{Political rationales}

State aid rules may also be regarded as a suitable tool to ensure a sensible use of public funds, including to avoid wasting public resources, for example in the form of "subsidy races" between regions or states. From the standpoint of local or national authorities, it might appear to be a sensible policy strategy to use subsidies to favour national producers' interests or to attract foreign investment, in order to create jobs. However, subsidies granted in one jurisdiction could lead to "retaliatory" measures in another. Moreover, when such aid merely shifts economic activity from a region to another, not really adding value or creating new activities, it can be globally wasteful. ${ }^{2}$

Hence, there is also a political rationale to state aid control since these subsidy races constitute an ineffective use of taxpayers' money, which may not be sufficiently disciplined through the democratic election process.

Naturally, subsidy races are more likely to emerge in regional free trade zones - the European Union (hereinafter also referred to as the "EU" or the "Union") being the ultimate example in this respect -, within federal states or countries with advanced regional autonomy, where cross-state or cross-region competition can be more easily developed. The phenomenon

\footnotetext{
${ }^{1}$ V. OECD, Competition, State Aids and Subsidies DAF/COMP/GF(2010)5, http://www.oecd.org/ officialdocuments/publicdisplaydocumentpdf/?cote=DAF/COMP/GF(2010)5\&docLanguage=En . On the historical foundations of the international regulation of subsidies up to the II World War, with a view to preserve the effectiveness of free trade agreements, v. Manuel Fontaine Campos, "A Concessão de Ajudas Públicas até à II a Guerra Mundial", Boletim de Ciências Económicas da Faculdade de Direito da Universidade de Coimbra LVI (2013): 238-241.

${ }^{2}$ For an overview of the economic rationales underpinning the granting and international control of subsidies, v. Manuel Fontaine Campos, "Fundamentos Económicos da Concessão de Ajudas Públicas no Mercado Nacional", Boletim de Ciências Económicas da Faculdade de Direito da Universidade de Coimbra LVII/I (2014): 943-974; and Manuel Fontaine Campos, "Fundamentos Económicos da Regulamentação Internacional da Concessão de Ajudas Públicas", Direito $e$ Justiça, Revista da Faculdade de Direito da Universidade Católica Portuguesa II (2015): 431-465.
} 
may, nevertheless, be further intensified by globalisation, thus leading local states or regions to engage in significant investments meant to shift activities from neighbouring states to themselves, without actually creating new activities.

In any event, regional trade blocs, in particular, may encourage supranational control systems, such as the EU, where stringent ex ante and expost rules are adopted.

However, this immediately begs the question as to whether such stringent control rules are appropriate within certain domestic jurisdictions and in relation to purely domestic aid, not affecting inter-state competition or trade, in particular within unitary and cohesive states - Portugal is the obvious example -, where a concern about "subsidy races" and potential inefficient allocation of resources between regions is not a primary concern.

\subsection{Fairness, equal treatment and market integration in the EU- addressing distortions caused by state aid}

Besides tackling the economic inefficiencies mentioned above, control over state aid is often justified for its mere distortive effects.

It is a well-known fact that the main rationale for state aid control in the Union has historically been market integration between Member States, with a view to ensure a level playing field between economic players throughout the internal market. ${ }^{3}$ This mantra on "maintaining a level playing field" and allowing all types of businesses to compete on equal footing has underpinned EU competition policy since its inception.

In this respect, the notions of fairness and equal treatment have always been pervasive as further goals of state aid law in the EU. In this respect, it is noteworthy that many of the European Commission's policy papers often declare that state aid law is meant to ensure fair competition and "equitable markets" throughout the EU, as a means to foster integration, whereas similar statements are rarely found in antitrust or merger control guidelines, which relate to policy areas driven by the maximisation of consumer welfare.

\footnotetext{
${ }^{3}$ For an overview of EU state aid law and economics, v. Franz-Jürgen Säcker and frank Montag, eds., European State Aid Law: A Commentary (Oxford: Bloomsbury Publishing, 2016); Herwig C. H. Hofmann and Claire Micheau, eds., State Aid Law of the European Union (Oxford: Oxford University Press, 2016); Kelyn Bacon QC, European Union Law of State Aid (Oxford: Oxford University Press, 2017); Philipp Werner and Vincent Verouden eds., EU State Aid Control - Law and Economics (Kluwer Law International, 2016).
} 
Indeed, in this regard, state aid law differs quite significantly from competition law, which, in my opinion, is less concerned with "fair" than with "free" (lawful) competition, as a means to protect consumer welfare, in the form of lower prices, quality, innovation and choice.

In any event, state aid like other forms of public intervention in the marketplace can cause competition distortions. These state-induced distortions to the marketplace may be categorised under what is sometimes called competitive neutrality. This notion has been widely defined by the OECD as a "principle according to which all enterprises, public or private, domestic or foreign, face the same set of rules, and where government's contact, ownership or involvement in the marketplace, in fact or in law, do not confer an undue competitive advantage to a market participant". Though the focus of competitive neutrality has often been on state-owned enterprises (SOEs), as opposed to private players, it may, in reality, encompass any form of public intervention, such as subsidies and state aid.

The obvious conceptual question to raise in this respect is whether there is a strong case to challenge aids that per definition entail some sort of distortive effect, that is, a certain degree of unequal treatment between market players, when no recognizable ensuing inefficiency, that is a restrictive effect to competition in the form of higher prices or output restriction, is likely to be identified.

\subsection{Conclusion}

In any event, in light of the above, state aid control and competition policy appear to be driven by similar concerns, including the underlying vision that free markets - including free from anticompetitive or distortive state favours - are more likely to deliver greater efficiency. Hence, to a large extent, state aid law, such as competition law, is also meant to foster competition on the merits, by protecting incentives of economic agents to deliver prices, quality, innovation and choice, while ensuring a level playing field between market participants, that is, an economic landscape more likely to elicit the benefits of competition for society.

\footnotetext{
${ }^{4}$ V. OECD, Roundtable on Competition Neutrality, DAF/COMP(2015)5 (2015), 4 http://www.oecd.
} org/officialdocuments/publicdisplaydocumentpdf/?cote=DAF/COMP(2015)5\&docLanguage=En . 


\section{The diversity of state aid regimes}

As a likely result of different historical backgrounds, control over state aids takes quite different forms from a jurisdiction to another.

At EU level, state aid rules are said to be a constituent element of competition law from its inception. The Treaty on the Functioning of the European Union (hereinafter "TFEU" or the "Treaty") reflects this situation, since the section on "aids granted by States" is a subsection of the chapter on "Rules on competition". The Treaty's competition rules are thus divided into "rules applicable to undertakings", which comprise competition law and rules on state aid control.

However, it is noteworthy that in many jurisdictions state aid control rules are absent from the competition law regime for perhaps quite opposite reasons related to the underlying systems of economic organization: either because, at one end of the spectrum, the state, as a rule, seldom directly intervenes in economic activities, either as a player or as a benefactor, hence a costly administrative control system may be regarded as unnecessary; or, at the other end of the spectrum, because the state's presence in the marketplace is so pervasive that it may be irrational to establish ground rules to curtail it (since the larger part of the economy is the State).

In Europe, it is useful to bear in mind that, not so long ago, several European economic systems rested upon a very different paradigm than that of a free market system, which was characterised by strong state interventionism and planning of entire sectors of the economy. Even the goal of the European Economic Community of a common market characterized characterised by "undistorted competition" was initially accepted by many Member States only with regard to inter-state trade and as an instrument to ensure peace, while their domestic economic systems were to a large extent still based on anticompetitive government planning.

This background may help to explain the need felt by the founders of the Treaty to establish compromise, middle-ground solutions and adaptable tools, such as state aid rules, to ensure the proper functioning of markets affected by governments, on the one hand, while declaring the Treaty's neutrality as to the public or private ownership of undertakings, on the other hand. 


\section{The Portuguese legal and institutional framework on domestic state aid}

In Portugal, despite the ban on state aid laid down in the Competition Act, the grant of state aid that does not affect trade between Member States is practically not prohibited. In effect, the national prohibition on state aid is enshrined in Article 65(1) of the Competition Act, which stipulates that aid granted by the State or by any other public entity to an undertaking should not restrict, distort or appreciably affect competition in the domestic market or in a substantial part thereof.

Apart from the requirement relating to interstate trade, the wording of this provision is quite similar to Article 107(1) TFEU, which establishes that, unless otherwise provided in the Treaties, any aid granted by a Member State or through state resources in any form whatsoever which distorts or threatens to distort competition by favouring certain undertakings or the production of certain goods shall, in so far as it affects trade between Member States, be incompatible with the internal market.

But despite their similar wording, these provisions differ in one crucial point, inasmuch as Article 65(1) of the Competition Act does not have any "teeth". Indeed, whereas the European Commission enjoys full (and exclusive) enforcement powers in relation to aid that may affect inter-state trade, including the very power to order the recovery of unlawful aid, at domestic level there is no prior notification procedure to the AdC or need for approval by the $\mathrm{AdC}$ before the aid in question is put into force. Moreover, there is no sanction or duty of recovery provided in the law, in case the aid is found to distort competition in part or in the whole of the national market.

In fact, the AdC does not hold full enforcement powers but only advocacy powers, that is, the power to issue recommendations as provided in Article 65(2) of the Competition Act. This provision establishes that the AdC may scrutinise any aid or aid project and issue recommendations to the government or to any other public entity as it deems necessary to remedy the negative effects on competition caused by public aid.

It is thus the government through its several departments that usually takes the ultimate decisions with regard to the granting of domestic aid and determines whether aid measures should be notified to the European Commission. 


\subsection{The underlying rationale of the Portuguese legal framework on domestic state aid}

A scenario whereby the AdC would hold full-fledged enforcement powers against state aid or hold decision-making powers to approve state aid measures might raise a number of challenges or policy concerns, which accounts to a large extent for this legal and institutional framework.

\subsubsection{The subjects of competition rules}

The typical tools of competition law enforcement are merger control (with the purpose of detecting and prohibiting those mergers that may significantly lessen effective competition) and, more importantly, the prohibition and often sanctioning of anticompetitive behaviour, including anticompetitive agreements (either vertical or horizontal) and abuses of dominance.

In effect, in most jurisdictions competition law is addressed to undertakings or enterprises, i.e. entities engaged in an economic activity regardless of their legal nature, ownership or source of funding. An economic activity may also be widely defined as the mere provision of goods and services (either for profit or non-profit). This notion, which has been developed by the case law of the Court of Justice of the European Union (ECJ), is codified, for example, in Article 3 of the Portuguese Competition Act.

Moreover, competition law is neutral as to the public or private ownership of undertakings, pursuant, for example, to Articles 2(2) and 4 of the Competition Act. As a result, so long as the State engages in an economic activity, for example through a SOE, it will be caught by competition rules.

Some practical implications of this situation include the fact that SOEs are subject to merger control and may actually be fined by the AdC in case they engage in anticompetitive behaviour.

However, aid granted by the State or by other public entities, such as other types of state-induced distortions, fits awkwardly into this equation, because the anticompetitive harm resulting therefrom may not be caused by an undertaking's autonomous behaviour, including by the State engaging in an economic activity, but by the State "wearing a different hat", i.e. the State vested in its powers of public authority or in the exercise of its sovereign functions, such as collecting taxes, through the grant of tax exemptions or subsidies. ${ }^{5}$

\footnotetext{
${ }^{5}$ For a study on the extent to which anticompetitive government action may be subject to antitrust challenge, v. Eleanor Fox and Deborah Healy, "When the State Harms Competition - The Role for Competition Law”, Antitrust Law Journal 79, 3 (2014): 769-819.
} 
This accounts for the fact that the AdC, unlike the European Commission, does not hold enforcement powers against the State or other public entities when the latter are vested in their powers of public authority. Though not impossible (and perhaps more conceivable against infra-state entities, such as municipalities or autonomous regions), it may be a sensitive issue to allow a national competition authority to sanction the government for its perhaps anticompetitive policy choices and to order it to remedy or revert them.

\subsubsection{Assessing the compatibility of state aid: a delicate balancing exercise between different public interest goals}

Strict enforcement of state aid control by national competition authorities, such as the AdC, might raise a second, perhaps more important, challenge: the fact that assessing the compatibility of state aid requires a delicate balancing exercise between sometimes conflicting public policy goals.

In effect, under EU law, the principle of incompatibility of state aid does not amount to a full scale prohibition, perhaps even more so further to the modernisation. Despite the negative effects resulting from unjustified aid mentioned earlier, there are of course many good rationales for state intervention through the granting of aids. State aid can be used to remedy market failures and produce positive externalities such as subsidising credit, fostering $\mathrm{R} \& \mathrm{D}$ and innovation, address cohesion concerns by reducing regional inequalities, etc.

As a result, the European Commission's way of handling individual cases typically revolves around a "balancing test" whose main elements include: (i) the identification of the objective of the aid as an objective of common interest; (ii) an examination as to whether the aid can bring about a material improvement that the market cannot deliver for itself (for example by remedying a market failure or addressing an equity or cohesion concern); (iii) an examination of whether the aid measure is an appropriate policy instrument (in the sense that it will achieve the purported goal and no less distortive measure is available); and (iv) finally, a balancing exercise between the expected positive impact of the aid and the expected competition distortions, which should remain limited.

This exercise is inherently based on a number of trade-offs over different public interest considerations. Moreover, the nature of the task implies that a competition authority may not be in the best position to take the ultimate decision as to which public interest goal should take precedence 
over the other (in the rare instances when they are impossible to reconcile). This is a moot exercise which ultimately relates to the role of the State in the marketplace. And it is the democratically elected municipality, government or parliament's acknowledged right to establish priorities and to choose between different social outcomes.

\subsubsection{Competition agencies should pursue clear-cut goals}

Full-fledged enforcement powers against state aid by the AdC might yet raise a third related challenge.

In fact, the effectiveness of competition enforcement relies to a great extent on the pursuit by competition agencies of unambiguous objectives when using the so-called competition law toolbox, including its powerful coercive and sanctioning measures. Indeed, in Portugal, the law includes a very clear statement in this regard. The AdC's mission, which is enshrined in Article 1 of its By-laws, consists in enforcing and promoting competition law, in order to foster an optimum allocation of resources and the interests of consumers in the country.

This means that the AdC's drive is straightforward and encapsulated in the law: it relates to economic efficiency in its several forms (allocative, productive, dynamic) and, therefore, to fostering the competitive process so as to maximise consumer welfare through lower prices, quality, innovation and choice. The law has thus unequivocally entrusted the AdC with the mission of using competition law enforcement as a "consumer welfare prescription".

Enforcement decisions should thus be solely based on legal and economic grounds, driven by the pursuit of consumer welfare protection, rather than on other political considerations (sometimes impossible to reconcile). This is key in ensuring transparency, legal certainty and credibility in the decision-making process, which, in turn, is paramount in spurring enterprise, investment and innovation. In order to be encouraged to enter the market and compete, companies need to be given a certain degree of predictability as to how competition agencies "do business". In effect, this is precisely the rationale underlying the idea of competition agencies' independence: to ensure transparency and predictability in enforcement decisions, agencies need to be protected from political interference (which can also be said to contribute to protect the political power and democracy itself from the influence of economic power).

Therefore, in the modern antitrust world, the AdC should not proactively further other public interest goals when using the competition law 
toolbox, no matter how relevant, such as employment, gender diversity, international competitiveness, financial stability, environmental protection, etc. A competition agency with "mixed" policy objectives would be a "Pandora box", which might raise significant risks for society, including, amongst others, taking contradictory decisions, sending confusing signals to the marketplace, more vulnerability to capture, under enforcement, under deterrence and inaction.

In short, the fact that the assessment on the compatibility of state aid requires a balancing exercise between different public interest goals entails consequences as to the appropriate institutional design of state aid control. In effect, such an exercise is feasible at EU level because of the multidisciplinary composition of the European Commission, which to a certain extent resembles a supranational government, inasmuch as its decisions are taken by a collegiate board whose members may take into consideration the diversity of EU policy goals in the decision-making process. Therefore, it seems logical that a similar assessment should not differ at domestic level. Moreover, any attempt at decentralising EU state aid law, similar to the modernisation carried out with respect to EU antitrust law, ${ }^{6}$ which might entail granting national agencies powers similar to those held by the European Commission, would need to address this difficult challenge: on the one hand, the importance of preserving agencies' independence, by insulating them from other public interest considerations (different than those related to consumer welfare protection) when it comes to competition law enforcement and, on the other hand, the need to take into account precisely those public interest considerations when it comes to the assessment of the compatibility of state aid.

\section{The role of competition advocacy}

For the reasons mentioned above, the AdC, as an organisation which is independent from the government, may not be in the best position to have decision-making powers as to which aids should be lawfully granted or to hold full-fledged enforcement powers against them.

That being said, this does not mean that the AdC should ignore the big social economic picture altogether. Quite the contrary.

\footnotetext{
${ }^{6}$ For a suggestion of a decentralised legislative framework in the area of state aid, v. José Luiz da Cruz Vilaça, "How Far should National Courts Go in Drawing all the Necessary Inferences from the Last Sentence of Article 88(3) EC?" in EU Law and Integration - Twenty Years of Judicial Application of EU Law, ed. José Luiz da Cruz Vilaça (Oxford: Hart Publishing, 2014), 220.
} 
There are important restrictions or distortions to the proper functioning of markets that do not qualify as competition law infringements, to the extent that they are not caused by undertakings' autonomous behaviour, but which actually flow, even if involuntarily, from the State. These restrictions may be just as (or even more) pernicious to market conditions, business conduct, and economic performance. For example, legal barriers to entry, direct award of exclusive rights, regulations influencing prices, advertising or marketing, favouritism towards some market players and against others, etc. ${ }^{7}$

Therefore, the AdC has been increasingly active in using its non-enforcement or advocacy powers in order to tackle state-induced distortions and promote competition in the economy. Such advocacy tools include both ex ante and ex post competition impact assessment of public measures, outreach and awareness campaigns targeted to the public sector, sector enquiries, market studies, policy briefs, opinions and recommendations addressed to public decision-makers.

The consistent role of the AdC in this field has been based on helping either the government or other public entities to take informed decisions when designing economic policies or when taking any measure that may have an impact on competition conditions, so that tax payers' money is used more wisely and efficiently.

In this respect, the AdC has been consistently engaged in raising awareness on the importance of carrying out a competition impact assessment of public measures and in actually building capacity to do so within the government, including by promoting training sessions and workshops addressed to government officials.

The AdC's intervention in this regard has also sought to identify alternative ways in which the State or other public entities can pursue their social and economic goals without unnecessarily distorting markets, that is, while ensuring the maximum benefits from competition (i.e. prices, quality, innovation and choice) or when this is impossible, at least to assist in identifying the costs of interventions to enable informed policy choice.

The ultimate objective has been to help to shape the design of the country's legal and economic landscape, in a way that will, in time, improve Portugal's overall competitiveness.

Thank you for your attention.

\footnotetext{
${ }^{7}$ V. an inventory of state restraints or competitive neutrality distortions: OECD, Discussion on Competitive Neutrality, DAF/COMP(2015)13 http://www.oecd.org/officialdocuments/publicdispl aydocumentpdf/?cote=DAF/COMP(2015)13/FINAL\&docLanguage $=$ En .
} 


\section{Conclusions - post scriptum}

In the wake of the economic and financial crisis, the enforcement of state aid control has undoubtedly gained momentum in the Union's agenda. Many of the policy statements that have followed this trend have highlighted the benefits of "fair competition", including that "competition gives people a wide choice of products, at prices they can afford. It encourages companies to innovate and invest. In short, competition makes sure that markets treat people fairly". In this regard, state aid rules are "there to defend fair competition, so our economy works for everyone". ${ }^{8}$

This increasing mantra on the importance of "fairness" in competition law has elicited some scepticism amongst commentators and practitioners. In particular, it has raised doubts as to whether the European Commission might be departing from the consumer welfare standard or from efficiency as a competition policy goal.

However, on the one hand, one should bear in mind that there are also efficiency concerns underlying the prohibition of state aid in the Union, as this article has sought to recall. Indeed, control of state aid and competition policy appear to be driven to a large extent by similar goals, including the underlying vision that free markets - including free from anticompetitive or distortive state favours - are more likely to deliver efficiency. Hence, to a large extent, state aid law, such as competition law, is also meant to foster competition on the merits, by protecting incentives of economic agents to deliver prices, quality, innovation and choice, while ensuring a level playing field between market participants, that is, an economic landscape more likely to elicit the benefits of competition for society. On the other hand, internal market integration has always been an EU competition policy goal since its inception; hence, the rise of this "fairness approach", including the need for equal treatment between market players, should not be seen as a major surprise. Obviously, caution should be taken to avoid that a similar approach or standard contaminates other areas of competition enforcement, namely antitrust and merger control, given the significant risks highlighted in this article that "mixed" policy objectives on those domains might raise.

In effect, the fact remains that the assessment on the compatibility of state aid with internal market rules may require a delicate balancing exercise

\footnotetext{
${ }^{8}$ See for example, the speech by Margrethe Vestager "State Aid and Fair Competition Worldwide" at https://ec.europa.eu/commission/commissioners/2014-2019/vestager/announcements_en.
} 
between different public interest goals, e.g. competition, financial stability, research \& development, social cohesion, employment, etc. This requirement entails consequences as to the appropriate institutional design of state aid control. In fact, such an exercise is feasible at EU level because of the multidisciplinary composition of the European Commission, which to a certain extent resembles a supranational government, inasmuch as its decisions are taken by a collegiate board, whose members may factor in the diversity of EU policy goals in the decision-making process. Therefore, it seems logical that a similar assessment should not differ at domestic level. Moreover, any attempt at decentralising EU state aid law, similar to the modernisation carried out in EU antitrust law, which might entail granting national agencies similar powers to those held by the European Commission, would need to address this difficult challenge: on the one hand, the importance of preserving agencies' independence when it comes to competition law enforcement, by insulating them from other public interest considerations (different than those related to consumer welfare protection) and, on the other hand, the need to take into account precisely those public interest considerations when it comes to the assessment of the compatibility of state aid.

That being said, there seems to be a straightforward advantage to this new found rhetoric by the European Commission - the fact that it signals a simpler, clear-cut message to the public at large. It is about popular, conventional wisdom, easier to understand by the common citizen than the economic, often intricate jargon, on dynamic, productive or allocative efficiencies that perhaps would better peace the minds of specialised stakeholders. In effect, efficiency as such has never been an easy selling pitch within Europe, when one is advocating towards non-specialised stakeholders such as businesses on the benefits of competition. Amongst firms, rivalry is usually perceived as a very good idea, so long as it is happening in someone else's backyard, whereas "fair play" or "levelling the playing field" can sound more meaningful for businesses and consumers alike.

For modern antitrust enforcers, grounding competition cases on sound economics can be as important as engaging society on the importance of competition. Bringing (vigorous) competition enforcement to the public eye can help agencies to be perceived by the community as the guardian of the citizens' right to competition, which will enhance their credibility and standing in society over time. In short, the European Commission's recent trend towards a more popular, less technocratic tone can be instrumental in bringing competition enforcement "down to earth". 


\section{Bibliography}

Bacon, Kelyn. European Union Law of State Aid. Oxford: Oxford University Press, 2017.

Fontaine Campos, Manuel. "A Concessão de Ajudas Públicas até à II" Guerra Mundial". Boletim de Ciências Económicas da Faculdade de Direito da Universidade de Coimbra LVI (2013): 213-244.

Fontaine Campos, Manuel. "Fundamentos Económicos da Concessão de Ajudas Públicas no Mercado Nacional". Boletim de Ciências Económicas da Faculdade de Direito da Universidade de Coimbra LVII/I (2014): 943-974.

Fontaine Campos, Manuel. "Fundamentos Económicos da Regulamentação Internacional da Concessão de Ajudas Públicas". Direito e Justiça, Revista da Faculdade de Direito da Universidade Católica Portuguesa II (2015): 431-465.

Fox, Eleanor, and Deborah Healy. "When the State Harms Competition - The Role for Competition Law”. Antitrust Law Journal 79, 3 (2014): 769-819.

Hofmann, Herwig C. H., and Claire Micheau (eds.). State Aid Law of the European Union. Oxford: Oxford University Press, 2016.

Pastor-Merchante, Fernando. "The Protection of Competitors under State Aid Law". European State Aid Law Quarterly 4, 15 (2016): 527-538.

OECD. Competition, State Aids and Subsidies, DAF/COMP/GF(2010)5 http://www. oecd.org/officialdocuments/publicdisplaydocumentpdf/?cote=DAF/COMP/ $\mathrm{GF}(2010) 5 \&$ docLanguage $=\mathrm{En}$.

OECD. Discussion on Competitive Neutrality, DAF/COMP(2015)13 http://www.oecd. org/officialdocuments/publicdisplaydocumentpdf/?cote=DAF/COMP(2015)13/ FINAL\&docLanguage $=$ En .

OECD. Roundtable on Competition Neutrality, DAF/COMP(2015)5 http:// www.oecd.org/officialdocuments/publicdisplaydocumentpdf/?cote=DAF/ COMP(2015)5\&docLanguage $=$ En.

Säcker, Franz-Jürgen, and Frank Montag (eds.). European State Aid Law: A Commentary. Oxford: Bloomsbury Publishing, 2016.

Vilaça, José Luiz. EU Law and Integration - Twenty Years of Judicial Application of EU Law. Oxford, Hart Publishing, 2014.

Werner, Philipp, and Vincent Verouden (eds.). EU State Aid Control - Law and Economics. Kluwer Law International, 2016. 